\title{
THE KUZNETS CURVE FOR MOTORCYCLES IN BRAZIL
}

Fabio Gama

PhD student at PPGE / UFJF

Federal University of Juiz de Fora (UFJF) Juiz de Fora, MG 36036-900, BRAZIL f140383@gmail.com

Suzana Quinet de Andrade Bastos Professor at PPGE / UFJF

Cnpq Productivity Scholarship

Federal University of Juiz de Fora (UFJF) Juiz de Fora, MG 36036-900, BRAZIL quinet.bastos@ufjf.edu.br

Tiana de Paula Assis Undergraduate in Economics at UFJF Federal University of Juiz de Fora (UFJF) Juiz de Fora, MG 36036-900, BRAZIL tianaweinmann@gmail.com

Luíza Carvalho Graduate student in economics at UFJF Federal University of Juiz de Fora (UFJF) Juiz de Fora, MG 36036-900, BRAZIL carvalholuiza0@hotmail.com

\begin{abstract}
This article evaluates the evolution of motorcycle adoption in Brazil. More specifically, we aim to empirically understand the relationship between the number of two-wheeled vehicles and the country's level of development, as well as some of the factors that reinforce vehicle adoption in determined areas. The work uses data for 5565 Brazilian municipalities from 2010 to 2016 and implements a fixed-effects panel model. The results indicate an inverse relationship between income and number of motorcycles, corroborating the hypothesis of a Kuznets curve for motorcycles and income level in Brazil. In addition to the validation of the increase in the number of motorcycles observed in the country in recent years, we also find evidence that the increase in the number of motorcycles in municipalities may be related to the drop in formal employment, and big municipalities have the lowest per capita motorcycle ratio.
\end{abstract}

Keywords: Motorcycles. Kuznets curve. Income level. Brazil.

\section{A CURVA DE KUZNETS PARA MOTOCICLETAS NO BRASIL}

\begin{abstract}
RESUMO
Este artigo avalia a evolução da adoção de motocicletas no Brasil. Mais especificamente, busca-se compreender empiricamente a relação entre o número de veículos sobre duas rodas e nível de desenvolvimento do país. O trabalho utiliza dados para 5565 municípios brasileiros no intervalo de 2010 a 2016, e implementa um modelo de painel com efeitos fixos. Os resultados apontam para uma relação inversa entre renda e número de motocicletas, corroborando a hipótese de uma curva de Kuznets para motocicletas e nível de renda no Brasil. Além da validação do aumento do número de motocicletas observado no país nos últimos anos, são encontradas evidências de que o aumento do número de motocicletas nos municípios pode estar relacionado com a queda dos empregos formais, além de que municípios maiores apresentam a relação motocicletas per capita mais reduzida.
\end{abstract}

Palavras chaves: Motocicletas. Curva de Kuznets. Nível de renda. Brasil. 


\section{INTRODUCTION}

According to the World Business Council for Sustainable Development (2004), motoring analyzes around the world usually focus on the automobile. However, studies that address the twowheel motorized vehicles should also be produced, especially in developing countries where its growth have presented a significant evolution. In Brazil, the portrait of mobility has been undergoing major changes in recent decades, mainly reflecting the intense and accelerated process of urbanization and disorderly growth of cities, as well as the increasingly intense use of individual motorized transport by the population.

Motorcycles stand out as the most economical means of transport that can generate jobs (SILVA et al, 2009). For Rodríguez et al (2015), a significant number of motorcycle users adopt this vehicle as a tool to increase their income through the provision of courier or taxi services ${ }^{1}$. For the author, it was also identified that users recognize that access to a motorcycle increases the possibility of getting a job or having an increased income. Thus, the motorcycle can be seen as an element of social inclusion for low-income individuals, as it enables its users to travel relatively easily to places previously unreached, without the long distances and inefficiency of public transport to long journeys preventing them (FIGUEIRÊDO; MAIA, 2013).

Another factor that can be determining for motorcycle adoption is the high population density. Analyzing a set of 153 countries, Nishitateno \& Burke (2014) verify that a country's population density and income levels have a major effect on motorcycle adoption, where countries with an average population density above the median have 3.5 times more motorcycles per 1000 inhabitants than countries with population density below the median. According to the authors, the population concentration makes people choose to use a motorcycle to avoid the problems related to traffic congestion in large cities.

Although social perception varies between locations, the motorcycle can be a mean of transportation associated with a lower socioeconomic status. The association between income and motorcycle ownership is different from the relationship between income and automobile ownership. Generally, the level of income determines car ownership or its dependency, while for motorcycles there is no increase in ownership across all income levels. In the case of low-income individuals, ownership increases with income growth, while in the case of middle income ownership stabilizes and begins to decline as income levels evolve. This relationship is determined by two factors: the increase in the level of economic activity leads to an increase in the per capita income and the need to travel; and the increase in income, allows greater accessibility to the motorcycle, especially among the middle and lower-middle income population (RODRÍGUEZ ET AL, 2015).

Worldwide, in low-income regions, the growth of the motorcycle fleet has outpaced economic development. In these countries, while gross national income (GNI) per capita has tripled, the motorcycle fleet has grown more than six times. A similar trend can also be seen in lower-middle income countries - Indonesia, Moldova, Philippines and Ukraine - where the GNI per capita has doubled while the size of the motorcycle fleet quadrupled (Figure 1).

\footnotetext{
1 In Brazil, low-cylinder range motorcycles compose a large portion of the production of this vehicle category, between 2003 and 2009, 80.2\% of the production was of $150 \mathrm{cc}$ motorcycles - characterizing the universalization process of the motorcycle between low-income population and service to the transportation and delivery of goods (VASCONCELLOS, 2013a). 
Nishitateno \& Burke (2014) verify a Kuznets curve explaining the relationship between motorcycle ownership and income of countries. The authors describe the increase in dependence on the vehicle and then, as economies develop, the fall in such dependence.

Figure 1 - Motorcycle fleet evolution - GNI per capita (1993-2014).

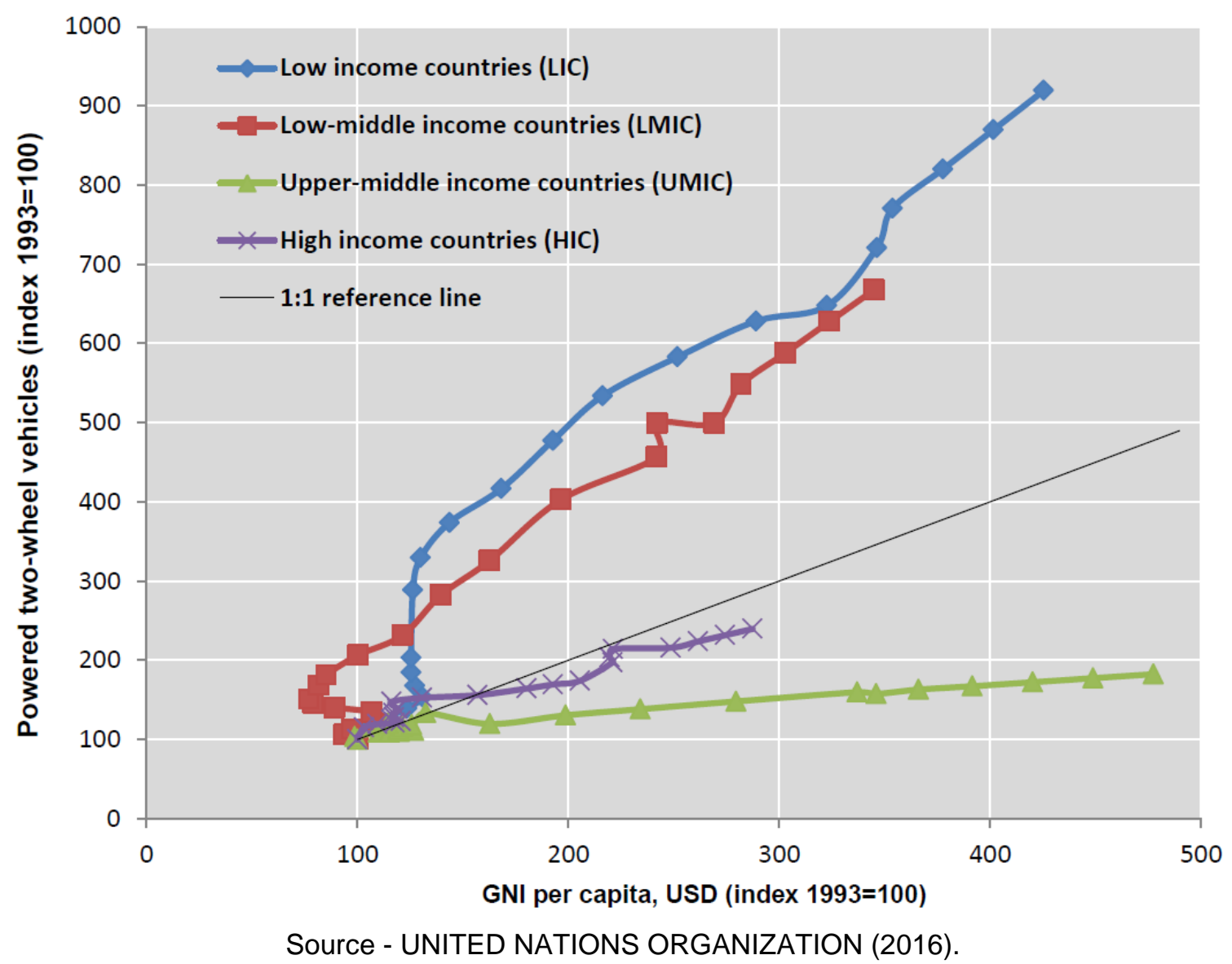

However, it is important to note that this process that shifts the function of the motorcycle in developed countries does not happen rapidly. Pongthanaisawan \& Sorapipatana (2010) point out that the relationship between motorcycle consumption and income level is composed by two stages. At an early stage of development, the number of motorcycles exceeds the number of other automobiles. At this stage, countries are considered low-income and the use of motorcycles is more viable due to the low purchase price. When these countries reach a higher income stage, the number of motorcycles tends to fall, while the fleet of other vehicles, especially cars, increases. At a certain inflexion point, individuals may prefer to consume cars over motorcycles, a change that occurs due to the increase in income ${ }^{2}$.

In this context, inspired by the work of Nishitateno \& Burke (2014), this paper aims to investigate the existence of a motorcycle Kuznets curve in Brazil. For the analysis of the relationship between income level and the rate of two-wheeled vehicle adoption we select data for 5565 municipalities in the period 2010 to 2016, employing the panel data method to estimate a fixed effect model.

The results indicate an inverse relationship between income and number of motorcycles, corroborating the hypothesis of a motorcycle Kuznets curve and income level in Brazil. In addition to the validation of the increase in motorcycle numbers observed in the country in recent years, there is also evidence

${ }^{2}$ When comparing automobiles and motorcycles, there is, in the background, a practice of encouraging individual transport to the detriment of the collective. 
that the increase in the number of motorcycles in the municipalities may be related to the decline of formal employment, and big municipalities present a motorcycle per capita ratio lower.

The study proceeds as follows. Section 2 discusses the empirical model and database. In section 3 , the results of the empirical application of the model are displayed. Finally, section 4 concludes the work.

\section{MOTOCICLE IN BRAZIL}

The Brazilian motorcycle sector started with the installation of Japanese companies' subsidiaries in Brazil. Before that, the sector was not organized and the few companies that were in the market did not have a sector structure. With the arrival of Yamaha and later Honda, the sector started to create a structure and configuration. The location chosen by these two companies for the opening of the factories was the ZFM (Zona Franca de Manaus), based on the tax incentive that the government offered to companies located in the region, to import high-tech equipment at competitive costs in relation to those produced in Brazil. Manaus, until today, is the industrial pole of the sector, comprising $98 \%$ of the motorcycle industries in the country

Until the end of the 1980s, the motorcycle was almost exclusively for high-income individuals, for leisure reasons. However, since the 1990s, its use has grown significantly, driven by the reduction of income inequalities and the increase in consumption among the poorest. The accelerated increase in this industry was initially supported by the release of imports in 1991. In addition, the government allowed the formation of consortia and financing systems, with lower interest rates. The sector's growth brought gains for companies based in the country, but on the other hand it attracted new competitors

More recently, the government's policy against the economic crisis that began in 2008 focused on reducing taxes and facilitating access to bank credit, with the auto and motorcycle industries being among the sectors targeted by this policy to encourage consumption. (SEERIG et al., 2016).

The growth of the national motorcycle fleet made it possible to increase the degree of mobility and access to private vehicles for low-income classes, even though it also produced negative consequences, such as the social costs generated by accidents ${ }^{3}$ and pollution ${ }^{4}$.

Although the growth of motorization is a widespread phenomenon, there are important regional and territorial differences. Between the end of 2007 and the end of 2008, motorcycle fleet grew in all regions of the country, however, with emphasis on North and Northeast regions which showed an increase of $20 \%$. From 2008 onwards, the increases continued to occur in all regions, but with variations that had been decreasing constantly every year. The 2018 data show that the value of this percentage change has stopped falling. In this case, positive variations occur in the South, Southeast and Midwest regions (RODRIGUES ET AL, 2019).

In 2018, the motorcycle fleet in Brazil was 26.4 million units, which represents an increase of $3.44 \%$ over the previous year. The largest number of motorcycles is located in the Southeast $(37.71 \%)$, followed by the Northeast (28.24\%), South (14.5), Midwest (10.1\%) and North (9.42\%). Based on the population size estimated in 2017 (IBGE), the municipalities with the highest motorcycle ownership were Pereiro, Ceará, where $53.94 \%$ of the population owns the vehicle, Tocantinópolis, Tocantins, and Água Branca, Piauí, with, respectively, $53.07 \%$ and $49.34 \%$ of the inhabitants owning motorcycles (DENATRAN, 2018).

According to Rodrigues et al (2019), in the metropolitan area of São Paulo, there was an increase of 80 thousand motorcycles between 2017 and 2018. In Fortaleza, more than 20 thousand motorcycles

3 The number of deaths in motorcycle accidents in Brazil has increased every year, as has the number of permanent disabilities as a result of accidents. Between 2000 and 2015, deaths increased from 2,465 to 12,066 deaths in the country, which represented an increase of $489.49 \%$ in the mortality rate in this category, being more prevalent among young men in Brazil, which corresponds to more than $50 \%$ of deaths among motorcyclists (SILVA ET AL, 2020 and (RODRIGUES ET AL, 2019).

${ }^{4}$ According to the Brazilian Institute for Environmental Protection (Proam), which represents non-governmental organizations (NGOs) in Conama, motorcycles pollute up to ten times more than automobiles of the same age, emitting especially volatile organic compounds, which react in the atmosphere with the heat stroke and create tropospheric ozone. In high concentrations, ozone causes lung, respiratory and allergy problems, mainly affecting children and the elderly (CARVALHO, 2011).

Caminhos de Geografia $\quad$ Uberlândia-MG $\quad$ v. 22, n. $82 \quad$ ago./2021 $\quad$ p. 191-200 Página 194


were added to its fleet. In general, in the 2008-2018 period, the motorization rate for motorcycles in the metropolitan areas went from 5 motorcycles / 100hab to 8.9 motorcycles / 100hab. However, this phenomenon is less than in the country as a whole where the motorization rate is 12.8 motorcycles / 100hab.

Brazilian regions also showed a significant change in their fleets, with 2,478 municipalities presenting more motorcycles than cars (Figure 2). In 2018, the Northeast had 7.46 million motorcycles and 6.67 million cars. The North also had a higher number of motorcycles compared to cars, with 2.49 million motorcycles and 1.67 million cars (CONFEDERAÇÃO NACIONAL DE MUNICÍPIOS, 2018).

Figure 2 - Municipalities with a higher number of motorcycles compared to automobiles (2018).

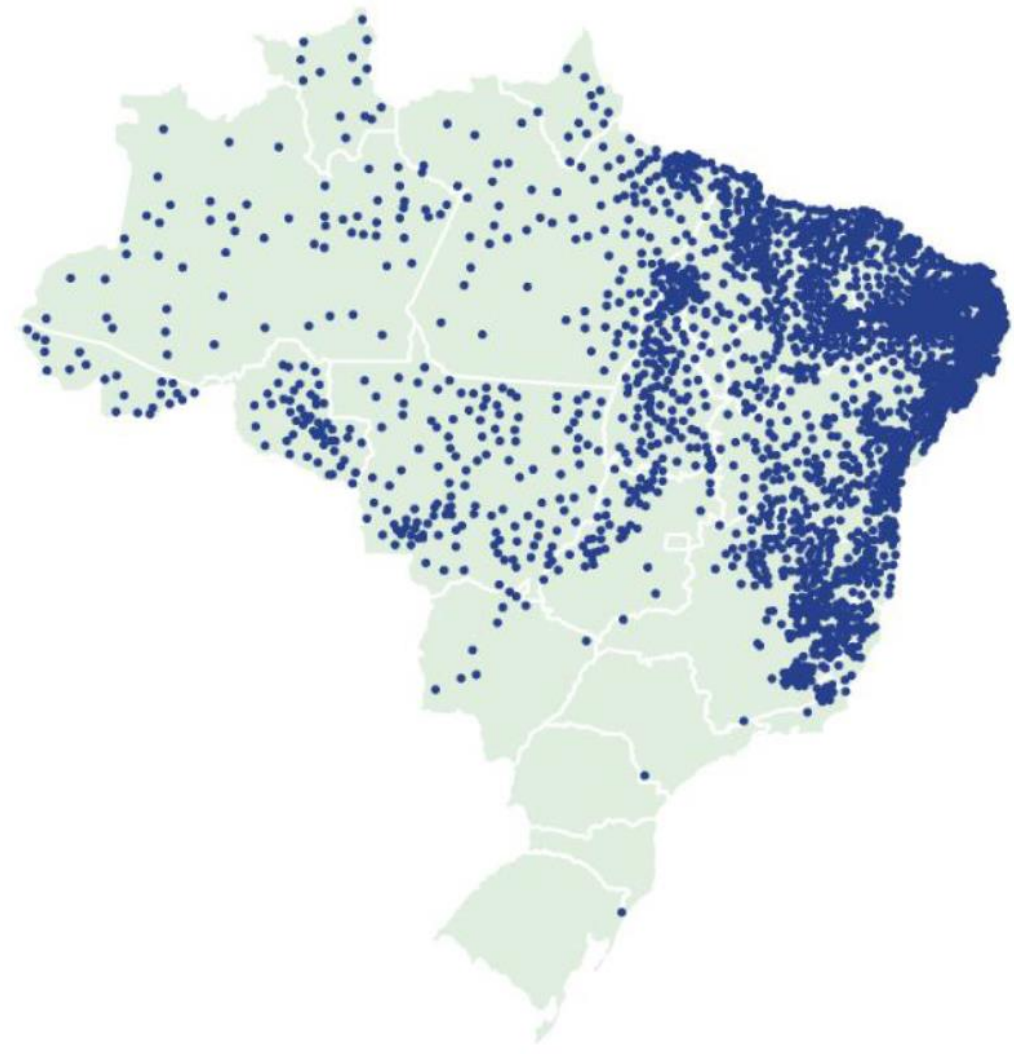

Source - CONFEDERAÇÃO NACIONAL DE MUNICÍPIOS (2018).

\section{DATABASE AND EMPIRICAL MODEL}

The per capita number of two-wheeled vehicles $\left(\right.$ mot $\left._{\text {pop }}\right)$ for each municipality is calculated from information on the number of vehicles reported by the National Traffic Department (Denatran) and the estimate of the total population produced by the Brazilian Institute of Geography and Statistics (IBGE). For the income proxy, data from Gross Domestic Product (GDP), also extracted from (IBGE), are used. Per capita GDP, ${ }^{p i b} b_{p e}$, is defined as the municipal GDP deflated at 2010 prices by the National Broad Consumer Price Index (IPCA), divided by the population estimate.

Figure 3 shows the dispersion between the logarithm of the number of two-wheeled vehicles per capita versus GDP versus GDP per capita. It is observed a nonlinear relationship between mot $_{\text {pop }}$ and $p i b_{p c}$, namely, in the case of municipalities with low income, the number of vehicles with two wheels per capita is low. On the other hand, when considering the municipalities with middle income, the two-wheeled vehicles/ population relationship increases, which indicates that the use of vehicles with two wheels responds positively to variations in income. However, the positive elasticity that is verified does not increase indefinitely as income increases, i.e. the relationship is 
concave, indicating a maximum point. Thus, as a municipality reaches a certain level of income, the ratio of two-wheeled vehicles / population begins to fall.

Figure 3 - Dispersion logarithm of per capita vehicles with two wheels versus GDP per capita.

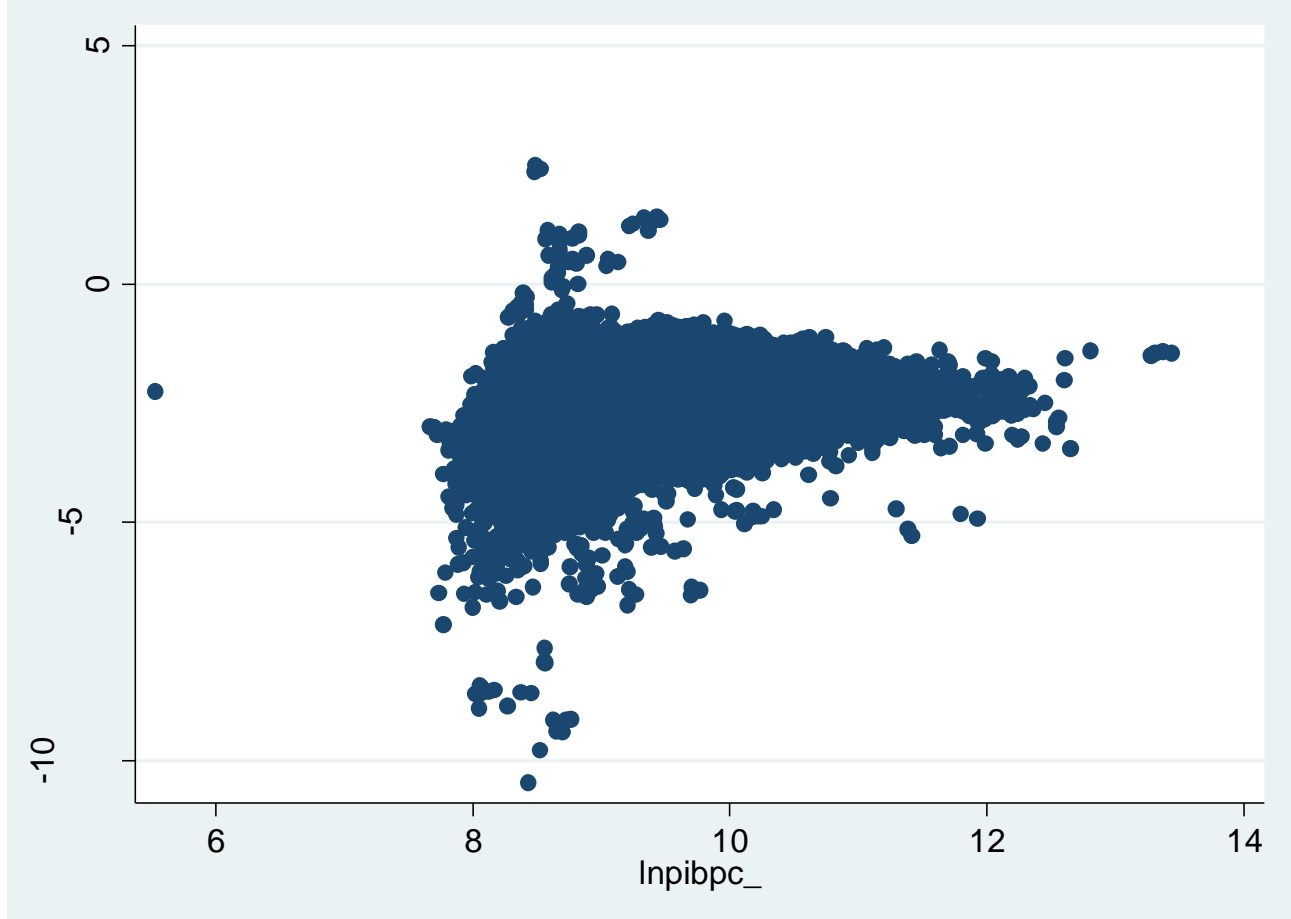

Source - Elaborated by the authors based on IBGE and Denatran data.

This concave relationship between logarithm of the number of per capita two-wheeled vehicles versus GDP per capita serves as an initial indication of the presence of a Kuznets curve between the use of vehicles with two wheels and income. According to Arraes et al(2006), one way to verify if two variables are related following the shape of a Kuznets curve is by estimating an econometric model, in which the explanatory variable of interest and its square are added. When the coefficient of the variable of interest is positive and the coefficient of its square term is negative, the hypothesis of Kuznets curve in concave shape is then validated - i.e. inverse-U shape.

Therefore, based on the Kuznets curve hypothesis between the number of motorcycles and GDP per capita, the panel data model to be estimated (1) is as follows:

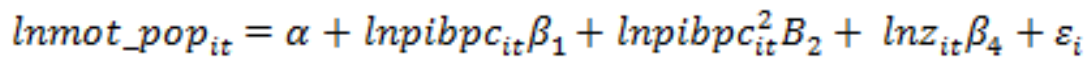

where, ${ }^{\text {lnmot_pop }}$ it is the natural logarithm of the number of two-wheeled vehicle per capita

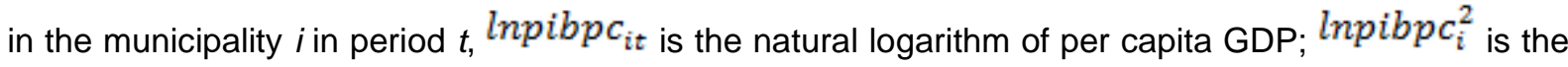
square of the natural logarithm GDP per capita; $l n z_{i t}$ is the natural logarithm of control variables; and $\varepsilon_{i}$ the random error term. The control variables used are: i) Index of human development, employment and income ( (nifirjan $_{i t}$ ), calculated by the Federation of Industries of 
the State of Rio de Janeiro (FIRJAN); (ii) demographic density ( lnden $_{i t}$ ), calculated based on the territorial area of the municipalities and the population size; iii) year dummies ( $D_{2011}, D_{2012}, D_{2013}$, $D_{2014}, D_{2015}, D_{2016)}$.

\section{APPLICATION}

To estimate the results, the panel data method is adopted. According to Almeida (2012), working with panel data, in general, has some advantages. First, there is the gain over the asymptotic properties of the estimators. Secondly, the method enables lower data collinearity, that is, the high level of information - information from several individuals - for explanatory variables reduces the probability of finding identical information for two or more regression variables. Additionally, the method allows the use of models that highlight the individual characteristic not observed, which is constant or random over time. In this way, the model admits the existence of differentiating characteristics of individuals that do not necessarily need to be among the vector of explanatory variables ${ }^{5}$ :

The procedure for estimating panel data models involves identifying and characterizing observed effects, which means comparing estimations by Pooled Ordinary Least Squares (POLS), Random Effects Panel (RE), Fixed Effects (FE), using Breuch-Pagan ${ }^{6}$ and Hausman tests ${ }^{7}$.

As can be seen in Table 1, the p-value of the Breusch-Pagan test recommends not accepting the null hypothesis at $99 \%$ confidence, indicating that the control of unobserved effects is the best fit. Given the evidence of unobserved effects, the next step is to identify their characteristic - fixed or random. For this, the Hausman test is applied, in which the p-value of 0.000 suggests that, at $99 \%$ confidence, the best method of estimation of the empirical model - equation 1 - is based on fixed effects (FE).

Table 1 - Specification Tests.

Breusch-Pagan (Unobserved Effects)

Hausman (Fixed Effects x Random Effects)
93668.51

592.14

$(0.000)$

\footnotetext{
Source: Elaborated by the authors based on the estimations.
}

${ }^{\dagger} p$-value in parentheses with ${ }^{\star * *} p<0.01,{ }^{* *} p<0.05,{ }^{*} p<0.1$.

The third column of Table 2 displays the results of the estimations, which is considered crosssection fixed effects and time and robust errors. The variables that measure the effect of income ( $l$ pibpc and $l n p i b p c^{2}$ ) on the number of motorcycles per capita ( ${ }^{l n m o t}$ poop) have significant coefficients and $99 \%$ confidence.

\footnotetext{
${ }^{5}$ For details on panel data model estimation procedures, see Wooldridge (2012).

6 To identify unobserved effects, the Bresuch-Pagan test is applied - which compares POLS estimates with the random effects model (RE). The Breusch-Pagan test has the null hypothesis that unobserved effects are not significant.

7 Hausman's test allows us to identify the best fit of data between random effects or fixed effects panel methods. HO: Random effects (RE) are more efficient. H1: Fixed effects (FE) are consistent.
} 
Table 2 - Panel estimation.

\begin{tabular}{|c|c|c|c|}
\hline & POLS & RE & $\overline{F E}$ \\
\hline \multirow[t]{2}{*}{ Inpibpc } & $3.460^{\star \star \star}$ & $2.300^{\star \star \star}$ & $1.775^{\star \star \star}$ \\
\hline & $(0.000)$ & $(0.000)$ & $(0.000)$ \\
\hline \multirow[t]{2}{*}{ Inpibpc ${ }^{2}$} & $-0.173^{\star \star \star}$ & $-0.114^{\star \star *}$ & $-0.089^{* \star *}$ \\
\hline & $(0.000)$ & $(0.000)$ & $(0.000)$ \\
\hline \multirow[t]{2}{*}{ Inifirjan } & $0.240^{\star \star \star}$ & 0.006 & -0.010 \\
\hline & $(0.000)$ & $(0.346)$ & $(0.189)$ \\
\hline \multirow[t]{2}{*}{ Inden } & $0.029^{* \star *}$ & $0.033^{* \star *}$ & $-0.710^{\star * *}$ \\
\hline & $(0.000)$ & $(0.000)$ & $(0.000)$ \\
\hline \multirow[t]{2}{*}{$D_{2011}$} & $0.115^{\star \star *}$ & $0.116^{\star \star *}$ & $0.125^{\star \star \star}$ \\
\hline & $(0.000)$ & $(0.000)$ & $(0.000)$ \\
\hline \multirow[t]{2}{*}{$D_{2012}$} & $0.207^{\star \star \star}$ & $0.215^{\star \star \star}$ & $0.230^{\star \star \star}$ \\
\hline & $(0.000)$ & $(0.000)$ & $(0.000)$ \\
\hline \multirow[t]{2}{*}{$D_{2013}$} & $0.253^{\star \star \star}$ & $0.261^{* \star *}$ & $0.304^{* * *}$ \\
\hline & $(0.000)$ & $(0.000)$ & $(0.000)$ \\
\hline \multirow[t]{2}{*}{$D_{2014}$} & $0.328^{\star * *}$ & $0.325^{\star * \star}$ & $0.373^{* \star *}$ \\
\hline & $(0.000)$ & $(0.000)$ & $(0.000)$ \\
\hline \multirow[t]{2}{*}{$D_{2015}$} & $0.437^{\star * *}$ & $0.391^{* * *}$ & $0.437^{* \star *}$ \\
\hline & $(0.000)$ & $(0.000)$ & $(0.000)$ \\
\hline \multirow[t]{2}{*}{$D_{2016}$} & $0.457^{* * *}$ & $0.427^{\star \star *}$ & $0.479^{\star \star \star}$ \\
\hline & $(0.000)$ & $(0.000)$ & $(0.000)$ \\
\hline \multirow[t]{2}{*}{ Constant } & $-19.666^{* * *}$ & $-14.246^{* * *}$ & $-9.11^{\star \star \star}$ \\
\hline & $(0.000)$ & $(0.000)$ & $(0.000)$ \\
\hline Observations & 38559 & 38559 & 38559 \\
\hline $\mathrm{R}^{2}$ & 0.171 & 0.160 & 0.003 \\
\hline
\end{tabular}

Source: Elaborated by the authors based on data from IBGE and Denatran.

Notes: Dependent variable: log number of motorcycles per capita. Error standard robust in parenthesis. ${ }^{* *} p<0.01,{ }^{* *} p<0.05,{ }^{*} p<0.1$.

Additionally, the signs of the coefficients follow the same pattern found in Nishitateno \& Burke (2014), indicating that the hypothesis of the Kuznets curve for the adoption of motorcycles in Brazilian municipalities is consistent, since the positive Inpibpc and the negative Inpibpc ${ }^{2}$ indicate that the relationship between the income variable and the dependent variable has an inverse $U$ shape - Figure 3. In other words, as incomes rise among municipalities, a larger number of motorcycles per capita can be observed, however, this relationship reaches a maximum point, suggesting that from this point on, higher income levels imply fewer motorcycles per capita.

For municipalities with higher levels of employment - lnifdmemprenda - lower number of motorcycles per capita is observed, indicating that the increase in the number of motorcycles may be related to the drop in formal employment. The negative coefficient for demographic density suggests 
that big cities have the lowest motorcycle per capita ratio. This is evidence, as already presented in Santana (2017), of a characteristic noted in Brazil, where it is verified that the proportion of motorcycles increases as the number of inhabitants decreases.

The coefficients of the year dummies indicate that the number of motorcycles per capita has increased in Brazilian municipalities. This pattern can be explained by the decline in per capita income occurred from the year 2012 in Brazil (World Bank, 2019) ${ }^{8}$. In addition, the great demand for services through applications - mostly autonomous services such as drivers, deliverymen, among others - may also reflected in a higher rate of motorcycle adoption in the country ${ }^{9}$.

Additionally, although the Breush-Pagan and Hausman tests indicate a better adequacy of the fixed effects model, the evidence presented by the estimates via POLS and random effects still suggests that the Kuznets curve hypothesis for motorcycle adoption in Brazilian municipalities is credible. This reinforces the results obtained through fixed effects, indicating that, the increase in income in the municipalities determines the increase in the rate of motorcycle adoption - at decreasing rates.

\section{FINAL CONSIDERATIONS}

The present work brings empirical evidence of the Kuznets curve for motorcycles in Brazil. Through the analysis of 5565 municipalities in the country, it is possible to identify the inverted $U$ shape between the adoption of motorcycles and income level. That is, the adoption rate of the vehicle on two wheels increases after a certain minimum level of income, evolves, and then reduces when the population reaches higher levels of income. In addition to the validation of the Kuznets curve for the Brazilian case, it is verified that this effect can be reinforced in municipalities where the human development, employment and income index is lower, as well as in municipalities with reduced population density.

Evidence shows the continuous increase in motorcycles ownership in Brazil. Having in mind the low level of income of the Brazilian population in general, it is expected that the country will still remain below the Kuznets curve turning point for a long period, experiencing the evolution of the motorcycle fleet. In this context, public policies aimed at promoting income and reducing Brazilian regional economic inequalities are recommended in order to allow greater access to comfort and safety promoted by four-wheel vehicles. In addition, for greater access to vehicles with two wheels to have positive impacts on social well-being, greater investments in infrastructure are necessary in order to promote safety and urban mobility with higher quality.

\section{REFERENCES}

ALMEIDA, E. S. Econometria Espacial Aplicada. 1a. ed. Campinas: Alínea Editora, v. 1. 498p., 2012.

ARRAES, R.A., DINIZ, M.B., DINIZ, M.J.T. Curva ambiental de Kuznets e desenvolvimento econômico sustentável. Revista de Economia e Sociologia Rural 44 (3), 525-547, 2006. https://doi.org/10.1590/S0103-20032006000300008

ASSOCIAÇÃO NACIONAL DOS TRANSPORTES PÚBLICOS (ANTP). Mobilidade humana para um Brasil, 2017 Available at: www.antp.org.br.

CARVALHO, C. Emissões relativas de poluentes do transporte urbano. p. 123-139, 2011 a.

CONFEDERAÇÃO NACIONAL DE MUNICÍPIOS. A Frota de Veículos nos Municípios em 2018. Estudos Técnicos/Trânsito. Junho de 2018.

DEPARTAMENTO NACIONAL DE TRÂNSITO (DENATRAN), 2018. Estatísticas da frota de veículos no Brasil. Available at: www.denatran.gov.br.

FIGUEIRÊDO, C. F.; MAIA, M. L. A. O Uso da Motocicleta e a Inclusão Social. Associação Nacional dos Transportes Públicos (ANTP), 2013.

MANDEL, M.; LONG, E.. A Economia de Aplicativos no Brasil, 2017.

8 According to the World Bank data (2019), Brazil, which in 2011 had a per capita income of about $\$ 13,000$, suffered continuous reduction in the indicator level, coming in 2015 with an income of less \$ 9,000 per capita.

${ }_{9}^{9}$ According to Mandel \& Long (2017), App Economy had generated 312,000 jobs in Brazil - January 2017 data. 
NISHITATENO, Shuhei; BURKE, P. J. The motorcycle Kuznets curve. Journal of Transport Geography, v. 36, p. 116-123, 2014. https://doi.org/10.1016/j.jtrangeo.2014.03.008

ORGANIZAÇÃO DAS NAÇÕES UNIDAS (ONU). Economic Commission for Europe, I. B. The United Nations motorcycle helmet study. New York; Geneva: United Nations, 2016. Available at: https://lccn.loc.gov/2015514316.

PONGTHANAISAWAN, J.; SORAPIPATANA, C. Relationship between level of economic development and motorcycle and car ownerships and their impacts on fuel consumption and greenhouse gas emission in Thailand. Renewable and Sustainable Energy Reviews, v. 14, n. 9, p. 2966-2975, 2010. https://doi.org/10.1016/j.rser.2010.07.034

RODRIGUES, J; AZEVEDO, S; RIBEIRO, L. Mapa da motorização individual no Brasil - Relatório 2019. Universidade Federal do Rio de Janeiro - UFRJ Instituto de Pesquisa e Planejamento Urbano e Regional - IPPUR, Rio de Janeiro, 2019.

RODRÍGUEZ, D.; SANTANA, M.; PARDO, C. La motocicleta en America Latina: caracterización de su uso e impactos en la movilidad en cinco ciudades de la región. (Despacio, Ed.). Bogotá: CAF, 2015.

SEERIG L. M. et al. Use of motorcycle in Brazil: users profile, prevalence of use and traffic accidents occurrence - a population-based study. Cien Saude Colet 21(12):3703-3710, 2016. https://doi.org/10.1590/1413-812320152112.28212015

SILVA, E. T.; RODRIGUES, J, M. Mobilidade Espacial nas Metrópoles Brasileiras: tendências dos movimentos intrametropolitanos, 2009.

SILVA, L; PEIXOTO, J; SANTOS, S; MAIA, L; SILVA, G; MOREIRA, R. Tendência de Mortalidade por Acidentes com Motocicleta: série temporal de 2000 a 2015. Saúde e Pesquisa, Maringá (PR), v13 n1, p123-132, 2020. https://doi.org/10.17765/2176-9206.2020v13n1p123-132

VASCONCELLOS, E. A. Risco no trânsito, omissão e calamidade [livro eletrônico]: impactos do incentivo à motocicleta no Brasil. São Paulo: Ed. do Autor, 2013a.

WORLD BANK. 2019. Available at: https://data.worldbank.org/indicator/NY.GDP.PCAP.CD

WOOLDRIDGE, J. M. Introductory econometrics: a modern approach (upper level economics titles). Southwestern College Publishing, Nashville, T ATN, v. 41, p. 673-690, 2012.

WORLD BUSINESS COUNCIL FOR SUSTAINABLE DEVELOPMENT (WBCSD). Mobility in the São Paulo metropolitan region: final report, 2004.

Recebido em: 06/07/2020

Aceito para publicação em: 22/10/2020 